Tinggalan Arkeologi Islam sebagai Bagian Perkembangan Sejarah Budaya di Kalimantan 94-105

\title{
TINGGALAN ARKEOLOGI ISLAM SEBAGAI BAGIAN PERKEMBANGAN SEJARAH BUDAYA DI KALIMANTAN
}

\author{
Bambang Sakti Wiku Atmojo* \\ Balai Arkeologi Banjarmasin, Jalan Gotong Royong II, RT 03/06, Banjarbaru 70711, Kalimantan Selatan; \\ Telepon (0511) 4781716; Facsimile (0511) 4781716
}

Artikel masuk pada 20 Maret 2012

Artikel selesai disunting pada 23 September 2012

\begin{abstract}
Abstrak. Tulisan ini mendeskripsikan beragam penelitian arkeologi dari masa pengaruh kebudayaan Islam yang telah dilakukan oleh Balai Arkeologi Banjarmasin di empat provinsi di Pulau Kalimantan sejak 1993. Penelitianpenelitian tersebut dilakukan dengan teknik survei berdasarkan tema kajian seperti arsitektur kuna, tata kota kuna, dan sejarah kebudayaan. Hasil penelitian menunjukkan bahwa peninggalan arkeologi masa Islam bervariasi, yaitu peninggalan bendawi dan non-bendawi. Peninggalan arkeologi bendawi terdiri atas peninggalan bersifat bangunan, struktur, situs, kawasan, dan artefaktual. Rentang periodisasi peninggalan arkeologi tersebut berasal dari abad ke15 sampai dengan ke-19 Masehi; peninggalan tertua berupa makam-makam abad ke-15 yang berada di Kabupaten Ketapang. Berdasarkan lokasi geografisnya, peninggalan-peninggalan monumental ataupun situs ditemukan pada kawasan pantai, daerah aliran sungai, dan perbukitan.

Kata kunci: tema penelitian, arsitektur, tata kota, sejarah kebudayaan, peninggalan arkeologi, bangunan, struktur, situs, kawasan, artefak

Abstract. ISLAMIC ARCHAEOLOGICAL REMAINS AS THE PART OF CULTURAL HISTORIC DEVELOPMENT IN KALIMANTAN. This paper describes various archaeological studies dated from the influence of Islamic culture that have been conducted by the Centre for Archaeology, Banjarmasin, in the four provinces of Kalimantan since 1993. These studies were carried out by survey based on research themes such as ancient architecture, ancient city planning, and cultural history. The results showed that Islamic archaeological heritage varies between tangible and intangible culture. The tangible archaeological heritage consist of buildings, structures, sites, regions and artefacts. The time range of the Islamic archaeological heritage is between the 15th until the 19th century; the oldest heritage is the 15th century graves located in Ketapang District. Based on the geographical location, monumental heritages or sites were found in coastal, basins and hilly regions.
\end{abstract}

Keywords: research theme, architecture, urban planning, cultural history, archaeological remains, buildings, structures, sites, regions, artifacts

\footnotetext{
* Penulis adalah Peneliti Madya pada Balai Arkeologi Banjarmasin, email: bambang.wiku@yahoo.com
} 
Tinggalan Arkeologi Islam sebagai Bagian Perkembangan

Sejarah Budaya di Kalimantan 94-105

\section{A. Pendahuluan}

Peninggalan arkeologi di Kalimantan yang berasal dari masa perkembangan agama Islam antara abad ke-15 - 19 Masehi tersebar di berbagai wilayah. Jenis peninggalan juga bervariasi, antara lain berupa artefak, struktur, bangunan, kompleks bangunan, dan kompleks kota lama. Peninggalan yang berupa artefak banyak yang berada di tangan masyarakat, museum provinsi atau kabupaten dan bekas istana. Rata-rata peninggalan artefak ini berupa alat kehidupan sehari-hari, senjata tajam tradisional, senjata api, dan kitab atau buku. Struktur dapat berupa sruktur bangunan tempat tinggal, struktur saluran air atau parit kota, fondasi bangunan baik bata atau batu, maupun struktur bangunan kayu. Bangunan utuh yang ada biasanya berupa masjid, istana, rumah pembesar kerajaan, dan cungkup makam. Kompleks bangunan biasanya merupakan bagian dari kompleks kota lama, yang terdiri atas kompleks pusat pemerintahan, pemukiman penduduk, dan unsur-unsur perkotaan yang lain.

Pada umumnya peninggalan tersebut merupakan bagian dari kerajaan-kerajaan Islam yang pernah ada di Kalimantan pada waktu itu. Dari empat provinsi yang ada di Kalimantan, sejauh ini hanya Kalimantan Tengah yang memiliki peninggalan arkeologi Islam paling sedikit. Peninggalanpeninggalan tersebut sebagian besar tersebar mulai dari daerah pantai timur Kalimantan Timur sampai dengan pantai barat Kalimantan Barat. Hal itu tidak terlepas dari posisi geografis kota-kota kerajaan-kerajaan tersebut yang rata-rata berada di tepi pantai, di muara sungai, atau di antara pertemuan dua buah sungai. Namun demikian, tidak sedikit peninggalan yang berada di daerah perbukitan atau daerah yang jauh dari pantai. Meskipun banyak peninggalan bangunan yang masih utuh, namun tidak sedikit pula yang sudah tidak utuh lagi. Sebagian di antaranya bahkan sampai dengan saat ini masih dimanfaatkan untuk berbagai keperluan, misalnya tempat tinggal.

Hasil penelitian yang dilaksanakan Balai Arkeologi Banjarmasin menunjukkan bahwa peninggalan tertua yang berasal dari masa perkembangan agama Islam di Kalimantan adalah makam-makam di Kabupaten Ketapang, Kalimantan Barat, yang menunjukkan berasal dari pertengahan abad ke-15 Masehi. Keberadaan makam-makam tersebut menunjukkan bahwa pada masa itu sudah terdapat pemukiman masyarakat muslim meskipun mungkin belum ada kerajaan yang bercorak Islam. Kerajaan tertua tampaknya adalah Kerajaan Banjar yang berdiri pada awal abad ke-16 Masehi, sedangkan yang termuda adalah Kerajaan Pontianak yang baru muncul pada abad ke18 Masehi. Kerajaan-kerajaaan yang lain berada di antara kurun waktu tersebut.

Tulisan ini mencoba untuk memaparkan hasil penelitian Balai Arkeologi Banjarmasin yang terkait dengan peninggalan arkeologi Islam di Kalimantan. Hampir semua penelitian menggunakan metode survei eskplorasi, kecuali ekskavasi yang dilakukan tahun 2006 di Martapura, Kalimantan Selatan. Penelitian yang dilaksanakan di empat provinsi wilayah kerja ini menghasilkan bermacam-macam data, baik yang bersifat tangible maupun intangible. 


\section{B. Kepurbakalaan Islam di Kalimantan 1. Istana}

Hasil penelitian menunjukkan bahwa di setiap kabupaten di Kalimantan Barat terdapat satu atau lebih kerajaan, yang peninggalannya sampai saat ini masih dapat disaksikan. Nama-nama kerajaan yang masih dapat ditelusuri adalah Sambas di Kabupaten Sambas, Mempawah di Kabupaten Pontianak, Landak di Kabupaten Landak, Sanggau dan Tayan di Kabupaten Sanggau, Sintang di Kabupaten Sintang, Tanjung Pura dan Matan di Kabupaten Ketapang, Kubu di Kabupaten Kubu Raya, dan Pontianak di Kota Pontianak. Jenis peninggalan yang ada antara lain meliputi istana, makam, masjid, benteng, bangunan tempat tinggal pembesar kerajaan, toponim kawasan pemukiman, dan parit keliling kota lama. Peninggalan yang sifatnya artefaktual antara lain alat kehidupan seharihari, meriam, perlengkapan perang yang lain, dan peralatan rumah tangga.

Semua kerajaan yang disebutkan di atas sampai dengan saat ini masih memiliki istana, kecuali Tanjung Pura. Istana-istana tersebut rata-rata masih dalam kondisi utuh, meskipun sebagian di antaranya dalam kondisi memprihatinkan atau tidak terawat. Hampir semua bahan yang digunakan untuk membuat istana adalah kayu ulin sehingga mampu bertahan sampai ratusan tahun. Di antara istana-istana tersebut sebagian di antaranya masih digunakan sebagai tempat tinggal raja atau keluarganya, misalnya di Sambas, Landak, Pontianak, dan Sintang. Istana terbesar adalah Istana Kodriyah di Kota Pontianak yang dibangun sekitar tahun 1771 dan memiliki dua lantai. Pada saat ini sebagian dari istana-istana tersebut difungsikan menjadi museum karena sudah tidak berfungsi sebagai pusat pemerintahan. Bangunan istana paling muda adalah Istana Landak dan Mempawah yang diresmikan pada tahun 1922 sebagai pengganti istana lama yang musnah terbakar. Kesamaan umum yang dimiliki oleh istana-istana tersebut adalah semuanya berada di tepian sungai besar yang merupakan urat nadi lalu lintas yang menghubungkan daerah pedalaman atau hulu sungai dengan kawasan hilir dan muara.

Di Istana Kodriyah Pontianak, Istana al Watzikubillah Sambas, dan Istana Amantubillah Mempawah terdapat pagar bata keliling. Pada pagar keliling istana Kodriyah bahkan dilengkapi dengan meriam yang berukuran cukup besar.

Di Kalimantan Timur peninggalan istana masih dapat dilihat di Berau, Tenggarong, dan Paser Balengkong. Istana di Berau ada dua, masing-masing merupakan peninggalan Kerajaan Gunung Tabur (Foto 1) dan Sambaliung. Istana Tenggarong merupakan peninggalan kerajaan Kutai Kertanegara, namun merupakan bangunan yang didirikan Belanda sekitar tahun 1930an. Berbeda dengan istana-istana yang lain di Kalimantan yang menggunakan bahan bangunan kayu, Istana Tenggarong dibuat dari bahan beton. Sementara itu, istana raja di Bulungan sudah hilang namun dari sisa yang ada menunjukkan bahwa terdapat juga pagar keliling yang berupa tembok, dan terdapat meriam sebagai pelengkap.

Masjid yang merupakan pusat lokasi peribadatan rata-rata berada di dekat istana yang merupakan pusat pemerintahan. Keduanya berada di tempat yang sama-sama tidak jauh dari aliran sungai besar. Di Sambas dan Landak, masjid kerajaan bahkan berada 
Tinggalan Arkeologi Islam sebagai Bagian Perkembangan

Sejarah Budaya di Kalimantan 94-105

pada satu kompleks dengan halaman istana. Sebagian besar masjid kerajaan memiliki bentuk atap tumpang tiga, ditopang dengan tiang-tiang kayu yang besar, sedangkan istananya, menggunakan konstruksi rumah panggung. Pada kasus di Kabupaten Ketapang masjid kerajaan sudah tidak dapat dilacak lagi keberadaannya.

Di kawasan sekitar istana dan masjid biasanya dikelilingi parit kuna yang merupakan batas kota raja, sekaligus merupakan benteng alam dari gangguan musuh. Parit keliling ini rata-rata lebar $3-4$ meter, dan berfungsi juga sebagai prasarana lalulintas perahu-perahu kecil. Sumber air biasanya diambilkan dari sungai yang mengalir di dekat tempat itu, dan dimuarakan kembali di sebelah hilir sungai tersebut. Sebagian di antara kanal-kanal tersebut saat ini sudah tertutup kawasan pemukiman, seperti yang terjadi di sekitar istana Sintang dan Sanggau. Di Landak, kanal keliling selain sudah tertutup oleh pemukiman, dan sebagian di antaranya juga tertutup oleh persawahan.

Peninggalan arkeologi Islam yang paling utama di Kalimantan Tengah terdapat di Kabupaten Kotawaringin Barat, terutama di Kecamatan Kotawaringin Lama dan Arut Selatan. Bangunan-bangunan yang masih ada di Kotawaringin Lama meliputi Astana alNursari, Masjid Kyai Gede, dan makam rajaraja di Kute Tanah. Bangunan-bangunan di Arut Selatan meliputi Istana Kuning, Istana Mangkubumi, kediaman Pangeran, serta makam raja-raja di Kute Batu, Pangkalan Bun (Hartatik, dalam Rangkuti 2009, 93-99).

\section{Makam}

Ada empat unsur yang menjadi aspek pengamatan dalam penelitian makam, yaitu bahan, bentuk atau tipologi, ragam hias, dan tata letak. Makam-makam yang dijadikan lokasi penelitian merupakan makam raja-raja atau anggota keluarga kerajaan, ulama, dan sedikit masyarakat kebanyakan. Lokasi makam berada di wilayah kerajaan yang berada di pantai timur Kalimantan, meliputi bekas Kerajaan Bulungan, Berau, Kutai Kartanegara, Paser, Batulicin, serta Pagatan, dan Koesan.

Makam-makam yang masih dapat ditelusuri kebanyakan berasal dari abad ke18 - 20 Masehi, yang merupakan masa jaya berbagai kerajaan di Kalimantan Barat, Kalimantan Timur, dan Kalimantan Selatan. Sebagai pengecualian adalah makammakam di Kabupaten Ketapang Kalimantan Barat, yang berasal dari abad ke-14 Masehi. Bahan yang digunakan untuk pembuatan nisan dan jirat makam ada empat jenis, yaitu 1) kayu, yang terdiri atas kayu ulin dan kayu biasa; 2) batu, baik marmer, granit maupun batu alam yang tidak diolah; 3) bata; dan 4) logam. Kayu merupakan barang asli dari Kalimantan, karena kayu ulin banyak tumbuh di hutan-hutan Kalimantan. Sampai saat ini ulin masih tumbuh di hutan pedalaman Kalimantan. Batuan marmer dan granit merupakan barang impor karena tidak ada tambang untuk kedua jenis batu tersebut di Kalimantan. Marmer merupakan barang dagangan yang masih diperdagangkan secara internasional sampai dengan saat ini. 
Dilihat dari segi bentuk, terdapat empat langgam nisan, yaitu langgam Aceh, DemakTroloyo, Bugis-Makassar, dan tipe lokal. Tipe lokal kebanyakan digunakan oleh masyarakat umum. Pada makam tokoh perempuan hanya ada satu langgam saja, yaitu pipih memanjang. Bentuk-bentuk jirat meliputi satu undak terbuka, kotak biasa bagian atas tertutup, undak dua, berundak lebih dari tiga, perahu sederhana, serta kotak bertingkat bagian atas terbuka. Adanya berbagai bentuk tersebut menunjukkan bahwa sejak ratusan tahun yang lalu telah terdapat pertemuan berbagai budaya Indonesia di Kalimantan. Meskipun demikian, tidak menutup kemungkinan bahwa nisan-nisan tersebut merupakan barang dagangan ataupun juga barang hadiah.

Ragam hias yang terdapat pada makam terdiri atas bentuk garis lurus, lingkaran, segitiga, dan jajaran genjang. Ragam hias flora meliputi bunga, daun, tangkai, dan stiliran bentuk kepala binatang. Ragam hias terawangan berupa ragam hias yang dipahatkan pada nisan atau jirat pada satu sisi sampai menembus sisi yang lain, biasanya berupa gambar daun-daunan atau garis lurus. Kaligrafi dapat berupa kaligrafi huruf Arab berbahasa Arab, huruf Arab berbahasa Melayu, huruf Bugis berbahasa Melayu, maupun huruf Bugis berbahasa Bugis.

Dilihat dari segi keletakan terdapat makam yang berada di dataran, di perbukitan, di perkotaan, di pedesaan, di daerah pemukiman, dan di luar daerah pemukiman. Kadang-kadang dalam satu kompleks makam dipisahkan antara makam tokoh raja dengan makam masyarakat. Pemisahan dilakukan dengan cara dicungkup, ditinggikan, dipagari, dan ditempatkan pada makam khusus.

Makam-makam pada umumnya berada di dekat kawasan istana, atau di pinggiran kota kerajaan. Namun demikian ada juga kompleks makam yang berada jauh di luar kota, misalnya seperti kasus yang ada di Bukit Rama untuk Kerajaan Mempawah, Mengkiyang untuk Kerajaan Sanggau, dan Mungguk untuk Kerajaan Landak. Tempattempat tersebut merupakan sebuah bukit yang dipercaya merupakan tempat sakral atau dipercaya sebagai asal-usul nenek moyang para pendiri kerajaan. Namun demikian ada sejumlah kesamaan dari kompleks-kompleks makam tersebut, yaitu tidak berada di tengah pemukiman. Bahan yang digunakan rata-rata kayu ulin, meskipun sebagian di antaranya menggunakan batu granit atau marmer. Ragam hias yang dipahatkan pada umumnya hiasan sulur-suluran dan kaligrafi Arab.

Di Kabupaten Ketapang terdapat dua kompleks makam yang oleh masyarakat dinamakan Keramat Tujuh dan Keramat Sembilan. Penamaan tersebut didasarkan pada jumlah makam kuna yang terdapat di tempat tersebut, yaitu tujuh dan sembilan. Siapa sebenarnya tokoh-tokoh yang dimakamkan di tempat tersebut tidak ada yang tahu secara pasti. Namun demikian, salah satu cerita lisan yang menyatakan bahwa tokohtokoh yang dimakamkan di tempat tersebut merupakan ulama penyebar agama Islam dari Majapahit. Menilik pada bentuk nisan yang mirip dengan bentuk nisan Troloyo (Foto 2) serta angka tahun Saka yang terpahat yaitu 1350, 1359 dan 1345, mungkin saja cerita lisan tersebut ada benarnya. Sampai sejauh ini angka-angka yang tertera di makam 


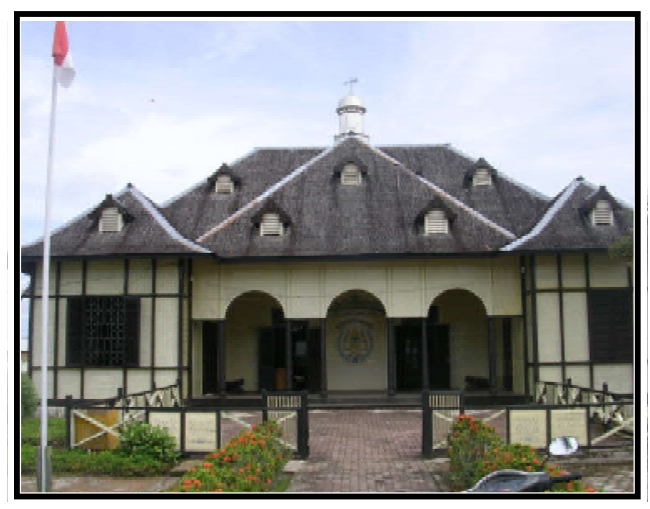

Foto 1. Istana Gunung Tabur di Berau, Kalimantan Timur (dok. Balai Arkeologi Banjarmasin)

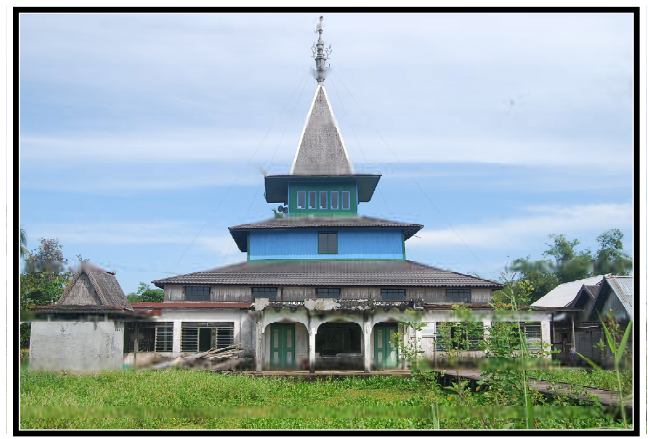

Foto 3. Masjid Assuada Waringin, Kalimantan Selatang (dok. Balai Arkeologi Banjarmasin)

tersebut merupakan angka paling tua pada peninggalan arkeologi Islam di Kalimantan Barat.

\section{Tata Kota}

Terdapat dua kota lama bekas ibukota kerajaan di Kalimantan Timur yang masih dapat ditelusuri bentuk-bentuk aslinya, yaitu Tenggarong dan Paser Balengkong. Tenggarong merupakan bekas ibukota Kerajaan Kutai, sekarang menjadi ibukota Kabupaten Kutai Kartanegara. Paser Balengkong merupakan bekas ibukota Kerajaan Paser, sekarang menjadi ibukota

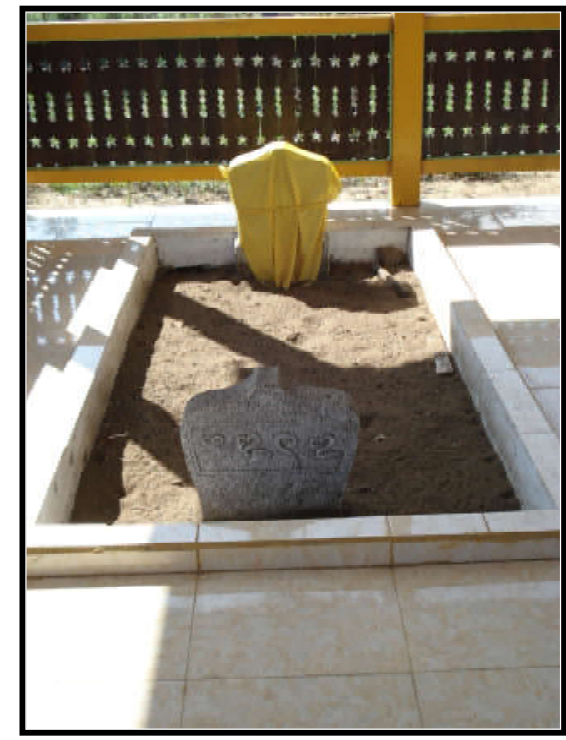

Foto 2. Salah satu makam di Kompleks Makam Keramat Sembilan, Kabupaten Ketapang (dok. Balai Arkeologi Banjarmasin)

Kecamatan Paser Balengkong. Tenggarong terletak di pertemuan Sungai Tenggarong dan Sungai Mahakam, sedangkan Paser Balengkong terletak di tepian Sungai Kendilo. Sungai-sungai tersebut pada masa lalu merupakan sungai yang ramai dilayari, namun pada saat ini hanya Sungai Mahakam yang masih tetap ramai dilayari dari hulu ke hilir maupun sebaliknya.

Hasil penelitian menunjukkan bahwa kota lama Tenggarong berukuran sekitar 1000 m X $750 \mathrm{~m}$, dikelilingi parit dan memiliki sejumlah bangunan kuna. Bangunanbangunan utama yang ada di Tenggarong adalah istana yang merupakan pusat pemerintahan, masjid Jami', bangunan penampungan, pasar, gedung bioskop, pelabuhan, penjara, parit kota, dan makam. Toponim yang masih ada antara lain Kampung Melayu, Kampung Panji, dan Bukit Pedidi. Kampung Melayu pada masa lalu 
dihuni oleh masyarakat Banjar, Kampung Panji merupakan kawasan pemukiman bangsawan, sedangkan Bukit Pedidi sebagian besar penghuninya masyarakat Bugis. Kota tersebut terbelah oleh Sungai Tenggarong menjadi dua bagian. Sampai saat ini Tenggarong tetap bertahan sebagai sebuah kota yang terus berkembang, terutama karena menjadi pusat pemerintahan kabupaten.

Agak berbeda dengan Tenggarong, Paser Balengkong hanya berada pada satu garis lurus di tepian sungai. Ukuran kotanya juga lebih kecil, yaitu sekitar 900 m X 650 m, yang juga dibatasi oleh parit keliling. Bangunanbangunan yang masih ada di Paser Balengkong di antaranya istana, masjid jami', kediaman raja muda, pasar, pelabuhan, parit keliling kota, dan makam.

\section{Arsitektur Masjid di Kalimantan Selatan}

Hasil penelitian di Kabupaten Tabalong, Hulu Sungai Utara, dan Balangan. menunjukkan bahwa perkembangan arsitektur masjid yang masih dapat dilacak terbagi menjadi tiga periode. Adapun perkembangan bentuk-bentuk arsitekturalnya yaitu:

a. Periode sebelum 1800 - 1900 Masehi. Masjid pada periode ini memiliki ciri atap meruncing tiga tingkat dan kemuncak berbentuk pataka dengan hiasan rumbairumbai berbentuk daun. Atap diperkirakan menggunakan daun rumbia. Lantai pasir, tiang kayu, memiliki tangga naik ke atap untuk adzan. Bentuk mihrab segi lima atau lebih dan memiliki kemuncak bentuk kubah. Contoh masjid dari periode ini adalah Masjid Pusaka Banua Lawas, Kecamatan Kelua, Masjid Assuada Waringin (Foto 3), Masjid Pandulangan, dan Masjid Pakacangan Lama.

b. Periode 1900 - 1945. Masjid dari periode ini memiliki ciri bentuk atap tumpang tiga landai, kemuncak kubah gaya India (Kubah Bawang), mihrab segi lima memiliki kubah, kadang memiliki jembatan antara kubah ruang utama dengan kubah teras depan. Terdapat hiasan pesawat atau pataka di atas kubah. Contoh masjid dari periode ini yaitu Masjid Jami' di Desa Pamatang dan Masjid Kamayahan

c. Periode 1945-1955 yang merupakan perpaduan antara gaya modern dengan gaya lama, misalnya atap tumpang tiga atau lebih dengan kemuncak kubah. Contoh masjid pada periode ini adalah pada Masjid Jami' Gelagah Hulu.

Bentuk mihrab di Kalimantan Selatan agak berbeda dengan daerah-daerah lain. Apabila dilihat di bagian dalam, atap mihrab berbentuk segi delapan, namun di bagian luar berbentuk segi lima. Selain itu seringkali juga mihrab masjid memiliki atap berbentuk kubah yang terpisah dengan kubah ruang utama.

\section{Perkembangan Peradaban Islam di Kalimantan Berdasarkan Peninggalan Arkeologis}

Mengacu pada berbagai peningalan yang ada, diperkirakan agama dan budaya Islam masuk ke Kalimantan pada abad ke-15 Masehi, yang dibuktikan dengan angka-angka 
Tinggalan Arkeologi Islam sebagai Bagian Perkembangan

Sejarah Budaya di Kalimantan 94-105

tahun yang tertera pada makam Keramat Tujuh dan Keramat Sembilan di Kabupaten Ketapang. Mungkin saja pada masa itu belum ada kerajaan yang bercorak Islam, dan baru ada pemukiman masyarakat Islam saja. Meskipun belum diketahui siapa tokoh-tokoh yang merupakan orang-orang Islam tersebut, namun menilik pada bentuk nisan yang mirip dengan makam Troloyo dan penulisan angka tahun diperkirakan mereka berasal dari Jawa Timur.

Perkembangan agama dan budaya Islam di wilayah Kalimantan yang lain terjadi setelah abad ke-15 Masehi. Pada buku-buku kronik lokal, misalnya Hikayat Banjar dan Salasilah Kutai tidak ada penyebutan angka tahun kapan masuknya agama dan budaya Islam di Banjarmasin maupun ke Kutai. Namun demikian, secara tersirat apabila dihubungkan dengan daerah lain tampaknya agama Islam masuk ke wilayah Kalimantan Selatan pada awal abad ke-16 Masehi, yaitu ketika Pangeran Samudera meminta bantuan Kerajaan Demak untuk membantu memerangi Pangeran Temenggung dalam mempertahankan hegemoni kekuasaan di wilayah Banjar. Pangeran Samudera setelah masuk Islam kemudian bergelar Sultan Suriansyah (Ideham dkk. 2005, 20; Sjamsuddin 2000, 20).

Di wilayah Kalimantan Timur tampaknya agama Islam disiarkan pada awalnya oleh ulama dari Sulawesi Selatan, yaitu Datuk Tunggang Parangan dan Datuk ri Bandang (Adham 1981, 224-236). Makam mereka berdua ada di daerah Kutai Lama, yang sekarang merupakan wilayah administratif Kabupaten Kutai Kertanegara. Di wilayah Kalimantan Tengah, agama dan budaya Islam berdasarkan tradisi dibawa oleh keluarga
Kerajaan Banjar yang mendirikan kerajaan vassal di Kotawaringin. Namun demikian, tidak menutup kemungkinan bahwa agama Islam di Kalimantan Tengah juga disiarkan oleh ulama dari luar Kalimantan. Ada juga ulama-ulama dari luar Indonesia yang menyebarkan agama Islam di wilayah Kalimantan, yang dibuktikan dengan keberadaan makam ulama dari kawasan Timur Tengah.

Kerajaan-kerajaan Islam baru muncul setelah memasuki abad ke-16 Masehi, yaitu dengan berdirinya Kerajaan Banjar pada tahun 1526, yang kemudian diikuti dengan munculnya kerajaan-kerajaan Islam lainnya di Kalimantan. Kerajaan yang berdiri paling akhir adalah Pontianak, yang berlokasi di pertemuan Sungai Landak dengan Kapuas, yaitu tahun 1771 (Hasanuddin, dalam Jauhari $2000,41)$ Pada awalnya, kota-kota tersebut tentunya merupakan sebuah pemukiman biasa yang kemudian berkembang menjadi sebuah desa dan memunculkan sebuah kota. Pada akhirnya kota tersebut menjadi kompleks, lengkap dengan berbagai sarana dan prasarana serta sebuah sistem pemerintahan. Meskipun demikian tidak semua tempat di tepi sungai dapat dijadikan kawasan pemukiman, hanya tempat-tempat tertentu saja yang memungkinkan.

Di antara kerajaan-kerajaan Islam yang ada di Kalimantan, dapat dikatakan bahwa Kerajaan Banjar yang memiliki wilayah pengaruh paling luas, yaitu di Kalimantan Selatan, Kalimantan Tengah, bahkan sampai Kalimantan Timur bagian selatan. Meskipun demikian pengaruh ini bukan berarti pada penguasaan wilayah atau pengakuan sebagai yang dipertuan, namun lebih banyak kepada pengaruh budaya. Salah satu pengaruh ini 
yang tersisa sampai sekarang adalah penggunaan bahasa Banjar yang digunakan sebagai bahasa pergaulan di wilayah tersebut. Nama-nama yang digunakan masyarakat di kawasan tersebut sebagian di antaranya juga masih terpengaruh nama-nama masyarakat Banjar. Salah satu contoh adalah penggunaan awalan Noor... dan akhiran ..syah pada nama seorang laki-laki.

Perkembangan tata kota kerajaankerajaan tersebut tetap dapat dilihat sampai dengan saat ini, meskipun kota-kota lama sudah berada di luar kota baru. Posisi kotakota kerajaan di Kalimantan hampir seragam, yaitu berada di tepian sungai besar atau di pertemuan dua sungai. Di depan istana terdapat halaman luas, dan kadang-kadang terdapat juga sejumlah bangunan yang digunakan untuk tempat tinggal raja dan keluarganya. Di Pontianak dan Landak, bahkan rumah para pembesar terdapat di kawasan istana yang dikelilingi pagar. Masjid sebagai pusat kegiatan keagamaan bisanya berada di kawasan istana juga, kecuali di Tenggarong dan Sanggau yang berada agak jauh dari istana.

Secara umum, terdapat berbagai pertimbangan mengenai keberadaan atau keletakan sebuah kota. Di antara berbagai pertimbangan tersebut adalah adanya pertahanan alam maupun buatan yang dapat melindungi dari serangan musuh, adanya kemudahan untuk mencapai kota, layak huni, serta konsep kosmologi dan simbolisasi (Paeni 2009, 276). Pada kota-kota kerajaan di Kalimantan, konsep pertahanan alam sekaligus kemudahan untuk mencapai kota diwujudkan dalam bentuk diletakkannya kotakota tersebut di persimpangan dua sungai atau lebih, sehingga terkesan sebuah kota diapit dua sungai pada kedua sisi kota. Adanya tembok keliling kompleks istana yang kadang dilengkapi dengan meriam, juga merupakan suatu upaya untuk melindungi diri dari serangan musuh. Kelayakan huni dilaksanakan dengan didirikannya sebuah kota di sebuah kawasan yang dapat digunakan untuk mendirikan bangunan secara permanen, serta jauh dari kawasan bencana. Jaringan jalan yang rapi juga terdapat di kawasan kota, yang berfungsi untuk menghubungkan dengan daerah sekitar kota dan membagi kawasan kota menjadi perkampungan. Sebagai contoh, di Pontianak dan Mempawah terdapat empat perkampungan yang dibatasi oleh jalan yang saling menyilang, sehingga memiliki sebuah perempatan besar di tengah kota. Selain jalan darat, di tengah kota dan pinggirannya juga terdapat jalan air atau kanal, yang memiliki berbagai fungsi. Di antara berbagai fungsi tersebut yang paling terlihat adalah untuk prasarana transportasi, sedangkan fungsi yang lain adalah untuk batas kota, batas antara kampung di dalam kota, sarana pertahanan, dan untuk pengairan.

Keberadaan kanal dalam struktur kota kerajaan Islam apabila ditelusuri ke belakang, memiliki kaitan dengan kota-kota pada zaman kerajaan Hindu-Buddha. Dalam mitos doktrin Hindu-Buddha, parit yang mengelilingi kota dianggap sebagai representasi samudera yang mengelilingi Jambudwipa. Mitos tersebut sangat kuat sehingga sungai seringkali juga dikeramatkan. Selain dibangun di dalam kota, kanal-kanal tersebut juga dibangun mengelilingi kota kerajaan. Selain di Indonesia, kanal juga dibangun di kota-kota kuna daratan Asia Tenggara. Fungsi kanal yang lain adalah sebagai pelengkap keindahan suatu 
Tinggalan Arkeologi Islam sebagai Bagian Perkembangan

Sejarah Budaya di Kalimantan 94-105

kota karena biasanya dipakai sebagai sumber air untuk taman kota (Dwiyanto 2002, 17; Reid $1999,103)$. Salah satu kota yang dikenal karena kanal-kanalnya pada masa lalu adalah Banjarmasin, yang sampai dengan saat ini sebagian kanal-kanal tersebut masih ada. Sebagian kanal memang sudah tertutup oleh pemukiman, namun bekas-bekasnya masih dapat ditelusuri kembali.

Sungai-sungai tersebut pada masa lalu merupakan jalan raya yang ramai dilayari sebagai prasarana perhubungan. Kapal-kapal ramai melayari sungai-sungai, menghubungkan daerah pedalaman dengan daerah hilir. Rata-rata kapal tersebut membawa hasil daerah pedalaman untuk dijual di daerah hilir, dan kembali dengan membawa berbagai barang keperluan sehari-hari yang tidak dapat dibuat di daerah pedalaman. Demikian pula sebaliknya, sebuah kapal datang dari hilir membawa berbagai keperluan untuk masyarakat hulu, dan kembali ke hilir membawa berbagai hasil daerah pedalaman.

Posisi kota kerajaan yang berada di tepian sungai besar atau di pertemuan dua buah sungai, merupakan posisi favorit karena dapat mengawasi kapal-kapal yang berlayar. Di depan kota terdapat pelabuhan tempat kapal berlabuh, yang tentunya harus membayar berbagai pajak kepada syahbandar. Pajakpajak tersebut disetor ke kas kerajaan untuk digunakan membiayai berbagai kegiatan yang dilaksanakan kerajaan.

Kota-kota kerajaan kadang-kadang mengalami perpindahan karena beberapa sebab, misalnya adanya wabah penyakit, bencana alam, ataupun gangguan keamanan. Kota lama yang ditinggalkan kemudian berubah menjadi desa atau bahkan hilang dari percaturan karena ditinggalkan penduduknya sama sekali. Kota Landak misalnya, pernah mengalami tiga kali perpindahan karena adanya bencana alam dan wabah penyakit (Yuliza, dalam Nurcahyani 2005, 1-5). Pada tahun 1768 penguasa kerajaan memindahkan pusat pemerintahan ke tempat yang berada di hilir sungai, yang bertahan sampai saat ini. Kota kerajaan lain yang juga sempat mengalami perpindahan adalah ibukota Kerajaan Banjar dan ibukota Kerajaan Kutai. Keduanya karena alasan yang hampir sama yaitu faktor keamanan yang mulai terganggu. Ibukota Kerajaan Banjar dipindah karena adanya perang dengan Belanda, sedangkan ibukota Kerajaan Kutai dipindah karena adanya serangan perompak. Pertikaian Banjarmasin dengan Belanda bahkan berlarut-larut sampai dengan meletusnya Perang Banjar tahun 1859 (Ideham, dkk. 2005, 20-22; Sjamsuddin dan Helius 2001, 99; Adham 1981).

\section{Penutup}

Mengacu kepada hasil penelitian maka dapat dikatakan bahwa konsentrasi pemukiman di Kalimantan mencakup tiga lokasi utama, yaitu pantai, daerah aliran sungai, dan perbukitan. Pada kawasan pantai terdapat peninggalan yang berupa makammakam, kawasan daerah aliran sungai terdapat perkotaan beserta isinya, dan kawasan perbukitan terdapat peninggalan berupa makam serta bekas-bekas sejumlah kota lama sebelum kota tersebut dipindah ke tempat lain. Berdasarkan hasil penelitian yang dilaksanakan Balai Arkeologi Banjarmasin, berbagai peninggalan fisik yang merupakan bukti eksistensi sejumlah kerajaan Islam pada masa lalu tersebar secara merata di empat 
provinsi di Pulau Kalimantan. Khusus untuk istana kerajaan, hanya Kalimantan Selatan yang tidak memiliki, sedangkan masjid dan makam tersebar di keempat provinsi. Peninggalan yang berupa pasar yang merupakan pusat kegiatan ekonomi masa lalu sudah tidak ada lagi, namun bekas tempatnya masih ada. Kadang-kadang tempat bekas pasar lama tersebut masih digunakan juga sebagai pasar tradisional masa kini.

Sejumlah bangunan fisik dari masa kerajaan Islam masih terpengaruh budaya bangunan pra-Islam, atau bahkan menggunakan tempat atau bahan dari tempat keramat masa pra-Islam. Sebagai contoh, misalnya batur yang menyerupai kaki candi pada kompleks makam Sultan Suriansyah di Banjarmasin, nisan makam di beberapa tempat di Kalimantan Timur yang menggunakan bentuk lingga semu, serta jirat sejumlah tokoh Islam di Kabupaten Ketapang dan Kayong Utara yang berbentuk batur candi. Atap masjid yang berbentuk tumpang merupakan peninggalan masa Islam yang tetap bertahan sampai saat ini. Perkembangan atap yang menggunakan kubah oleh masyarakat lebih dipandang sebagai suatu upaya praktis saja. Atap kubah lebih mudah dibuat daripada atap berbentuk susun atau tumpang. Meskipun demikian tidak dapat dipungkiri bahwa kubah merupakan budaya yang berasal dari luar Indonesia.
Secara non fisik, peninggalan dari masa pra-Islam ada dalam bentuk berbagai macam adat yang dibalut dengan ajaran Islam, misalnya tradisi haul (peringatan kematian seseorang yang dibarengi dengan pembacaan wirid dan sejumlah Surat dalam Al Qur'an), berdoa menggunakan ayat-ayat Al Qur'an sambil membakar dupa, serta acara baayun maulud pada bulan kelahiran Nabi Muhammad. Sejumlah kalangan masyarakat Dayak bahkan juga terpengaruh ajaran Islam meskipun mereka tidak beragama Islam, misalnya dalam membaca mamang (mantera) diawali dengan membaca bismillah. Di Masjid Pusaka Banua Lawas, Kalimantan Selatan bahkan juga dijadikan tempat ziarah masyarakat Dayak yang menganggap tempat tersebut pada masa lalu merupakan tempat berdirinya bangunan suci mereka.

Dapat dikatakan bahwa perkembangan budaya Islam di Kalimantan pada saat ini tetap terdapat pengaruh dari berbagai anasir budaya. Hal tersebut dapat dipahami mengingat ketika agama Islam sampai di Kalimantan, berjalan melewati berbagai wilayah baik di Asia maupun Indonesia, bahkan pada perkembangannya yang kemudian juga terdapat pengaruh budaya Eropa. Kondisi tersebut memperkaya perbendaharaan kebudayan Islam yang ada di Kalimantan, yang tetap dapat bertahan sampai dengan saat ini. 
Tinggalan Arkeologi Islam sebagai Bagian Perkembangan

Sejarah Budaya di Kalimantan 94-105

\section{Referensi}

Adham, D. 1981. Salasilah Kutai. Jakarta:

Proyek Penerbitan Buku Sastra

Indonesia dan Daerah

Departemen pendidikan dan

Kebudayaan.

Dwiyanto, Djoko. 2002. Selokan Mataram: tinjauan historis dan arkeologis. Majalah Artefak edisi Oktober 2002. Yogyakarta: Fakultas Sastra Universitas Gadjah Mada.

Hasanuddin. 2000. Kampung Dalam Bugis: dalam lintasan sejarah perkembangan Kerajaan Pontianak dan Kota Pontinak. Laporan Penelitian Balai Kajian Jarahnitra Pontianak. Jakarta: Direktorat Sejarah dan Nilai Tradisional Depdiknas.

Hartatik. 2009. Kontinuitas budaya di Kabupaten Kotawaringin Barat, Kalimantan Tengah. Dalam Rangkuti (ed.) Berita Penelitian Arkeologi 3 (1).
Ideham, M. Suriansyah. 2005. Urang Banjar dan kebudayaannya. Banjarmasin: Pemerintah Provinsi Kalimantan Selatan.

Paeni, Mukhlis. 2009. Sejarah kebudayaan Indonesia. Jakarta: PT Raja Grafindo Perkasa.

Reid, Anthony. 1999. Dari ekspansi hingga krisis II, jaringan perdagangan global Asia Tenggara 1450 1680. Jakarta: Yayasan Obor Indonesia.

Sjamsuddin, Halius. 2001. Pegustian dan temenggung: akar sosial, politik, enis, dan dinasti. Jakarta: Balai Pustaka.

Yulizas. 2005. Gelar bangsawan di Kerajaan Landak dan penggunaannya. Lisyawati Nurcahyani (editor) Jurnal Sejarah dan Budaya Kalimantan. Pontianak: Balai Kajian Sejarah dan Nilai Tradisional Pontianak. 